\title{
The Performance of Distribution Government Assistance toward School Dropout Communities Based on the E-Proposal Banper Management Information System, Organizational Transformation and HR Capabilities in Course Institutions
}

\author{
Eva Komalasari ${ }^{1}$, Mombang Sihite ${ }^{2}$, Edy Supriyadi ${ }^{3}$ \\ UNIVERSITAS PANCASILA \\ Email: evakomalasari2016@gmail.com; mombangsihite@univpancasila.ac.id; \\ edyyadi2@univpancasila.ac.id
}

Received: March $8^{\text {th }} 2021$

Approved: April 20 2021

\begin{abstract}
The purpose of this study was to evaluate the performance of the distribution of government assistance to dropout communities based on the e-proposal management information system, organizational transformation, and human resource capabilities of course institutions. The sampling technique was purposive sampling — data collection using questionnaires and FGD. The data analysis technique used Structural Equation Modeling (SEM) analysis processed with Smart PLS software. The research results prove that organizational transformation does not directly affect organizational performance in the distribution of government assistance. Meanwhile, HR capabilities and management information systems of e-proposal Banper directly affect organizational performance in the distribution of government assistance. Then organizational transformation indirectly has a significant effect on organizational performance in distributing government assistance by mediating the management information system e-proposal Banper. Likewise, human resource capability indirectly has a significant effect on organizational performance in distributing government assistance by mediating the management information system e-proposal Banper. The results of the strategy analysis through the input strategy stage with CPM, matching stage with TOWS, and decision stage with QSPM, concluded that the strategy used from the QSPM results is a strategy for developing SIM e-proposal assistance.
\end{abstract}

Keywords: Organizational Transformation, HR Capabilities, SIM e-Proposal Banper, Organizational Performance. 


\section{Introduction}

The challenges to unemployment, poverty, and children dropping out of school are still a serious concern by the government that addressed immediately. In August 2019, Central Bureau of Statistics (BPS in Indonesia) data showed that there were still 7.05 million unemployed people, while the total workforce in August in Indonesia reached 197.92 million people. Meanwhile, the citizenship poor of in September 2019 was recorded at 24.79 million people from the total population in Indonesia or $9.22 \%$ of the total population of Indonesia. The majority of the workforce $(58.77 \%$ / 72.8 million) have low levels of education (junior high school graduates/equivalent) without the skills required by the labor market (Anggraeni, 2019).

Information technology also contributes to the empowerment of national economic activities, as evidenced by the increasing activity of the industrial and SMEs, especially in Indonesia (Sani, Wiliani, Budiyantara, \& Nawaningtyas, 2020). Individuals and organizations cannot evade the era of the Fourth Industrial Revolution (Industry 4.0) in any part of the world by utilizing the latest technological bases. This concept of Industry 4.0 in Indonesia switches to the up-to-date technology and degrading the workforce (Sarwani \& Husain, 2021). Meanwhile, the demographic bonus marked by the high number of productive age populations that Indonesia will achieve in 2030 must be accompanied by the preparation of the quality of human resources to have good competitiveness. According to APO (2018), Indonesia's labor productivity is relatively low (1.37\%) when compared to neighboring countries such as Thailand $(5.28 \%)$, Vietnam (4.39\%), and Malaysia (2.16\%) (Kementerian Pendidikan dan Kebudayaan RI, 2020). Economic conditions/poverty is one of the factors that often underlie children not continuing their education. They drop out of school because of a lack of funds, while education requires a lot of money, especially formal education. To tackle school dropouts, the government, in this case, the Ministry of Education and Culture, provides alternative services through courses and training through vocational education.

Many of the management of the course and training institutions are still running in classical and manual ways so that they require a touch of technology design in a course and training institution management system. The strategic objectives that the Government wants to achieve in the distribution of Government Assistance to the Community are the implementation of life skills education for work and entrepreneurship that is of national standard, gender insight, education for sustainable development (ESD), and global citizenship (Permendikbud RI, 2018). Government assistance is packaged in the form of an information system to expand access to government assistance to citizens to make it effective and right on target and increase transparency, accountability, and credibility in the management of government assistance.

Data on Course and Training Institutions according to the NPSN (National School Principal Number) as of October 2020 is as many as 23,357-course institutions with various types of skills. Course Institutions and Training Institutions are two non-formal education units as stated in article 26 paragraphs (4) of Law no. 20 of 2003 concerning the National Education System. In general, Article 26 paragraph (5) explains that courses and training are held for people who need knowledge, skills, life skills, and attitudes to develop themselves, develop professions, work, work independently, and/or continue their education advanced high. Besides, it is supplemented again in Article 103 paragraph (1) of Government Regulation No. 17 of 2010 concerning the management and implementation of education that courses and training are held for the 


\section{Journal of Management and Leadership}

Vol.4 No.1, May 2021

community to develop a professional personality and improve the vocational competence of course students. Based on data on Pendidikan Kecakapan Kerja (PKK) and Pendidikan Kecakapan Wirausaha (PKW) assistance from 2015 to 2019, the Government has realized assistance funds of 812,579 students to run PKK and PKW programs.

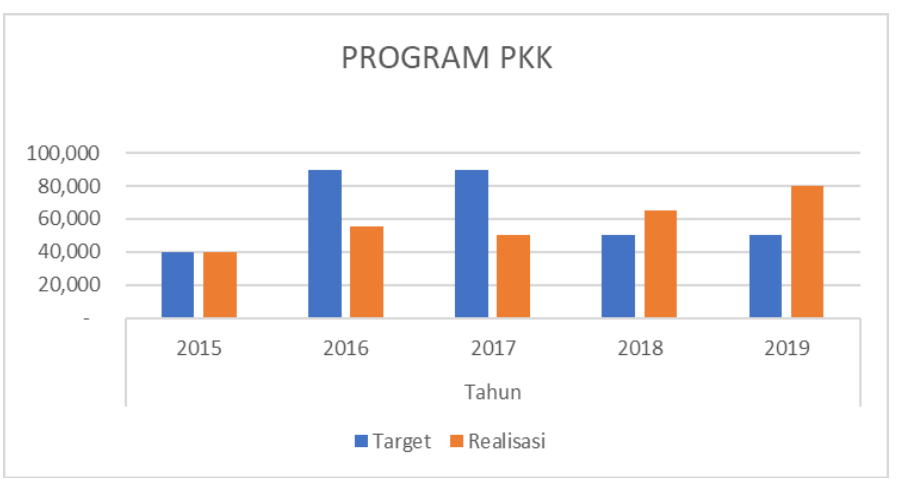

Chart 1, Realization of the distribution of PKK Program Government Assistance in 2015-2019 (processed by author)

The realization of Government Assistance for the PKK program from 2015 - 2019 saw an increase in the realization of this program because there was a lot of interest in the program. From 2015 to 2018, receiving proposals until the assessment was carried out manually so that many obstacles occurred. Due to this, the Directorate of Courses and Training has innovated in the admissions process to assessing proposals for government assistance, but this still has problems with the distribution of government assistance, namely that many agencies that access assistance do not understand online applications and are ignorant of information on how to access assistance program assistance. PKK, Assessment of PKK program funding assistance proposals is carried out through an online application, so the Assessment Team must understand the features of the assessment in the application to be applied to the assessment carried out following technical instructions and lack of socialization regarding the use of online government assistance applications.

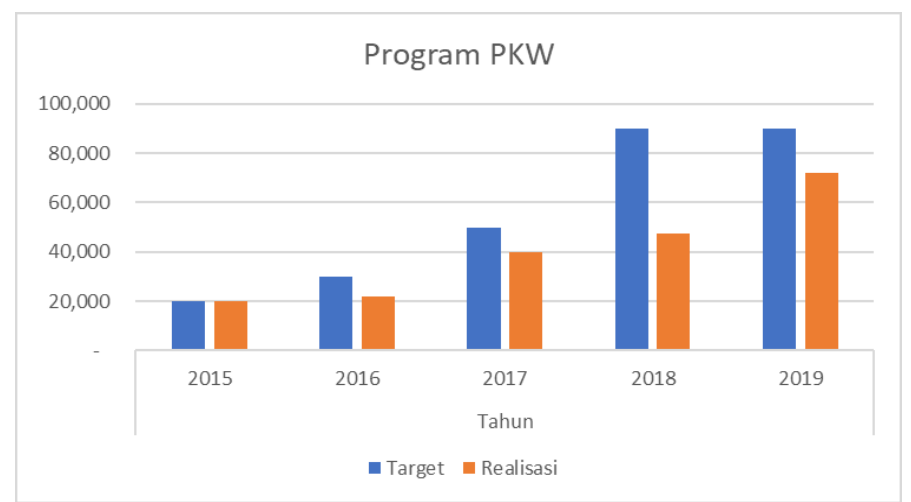

Chart 2, Realization of the distribution of PKW Program Government Assistance in 2015-2019 (processed by author)

PKW is an entrepreneurial education and training service program and entrepreneurial skills organized by course and training institutions (LKP in Indonesia) or other PNF units, course partner organizations and professional associations, DUDI, and educational institutions that carry out vocational functions tailored to business needs and opportunities that exist in the community. This program is similar to the PKM program held during the period 2010 - 2015. This assistance is provided to the community with certain criteria such as unemployed and/or do not have a 
permanent job, dropping out of school or graduating, not continuing (not taking learning in school/college or equivalency education programs), aged 16-40 years, specially recruited (special classes) at PKW administering course institutions, must be separated from regular (self-help) students at PKW administering institutions, and are not currently participating in educational programs and similar training funded from APBN / APBD. The existence of an e-banper system as an online government assistance application is expected to improve organizational performance, especially course and training institutions that collaborate with the government in distributing PKK programs and PKW programs. Robbins and Coulter (2012) state that: "organizational performance is the accumulated results of all the organization's work processes and activities." The organizational performance of the course and training institutions is indicated by an indicator of the increasing number of participants taking courses and training from the government.

Wijaya (2011) stated in the results of the National Seminar on Information Technology Applications that an integrated information system is a valuable company asset, where if it is properly implemented, the information system will have an impact and added value for the company to be competitive and increase business success until the long term. Based on Paul Chwelos, Izak Benbasat, and Albert S. Dexter research, another factor that supports the acceptance of information technology is pressure originating from the external environment (external pressure), which influences one another, such as competitive forces, industrial impulses, and the influence of trading partners (Husain, 2017). To achieve this, it must be considered seriously about the influence of information technology and organizational changes to support the implementation of an information system built to be successful and according to the needs of company management. Data in information systems should be integrated data from all company units or organizations so that used for various task needs within the company (Wijaya \& Novita). Implementation of management information systems can improve an organization's ability to solve various existing problems. One of the problems is an organizational transformation and human resource capabilities.

Organizational transformation is the process of organizational change that includes structures and processes to improve performance according to the dynamics of the development of the organizational environment. An organizational life cannot separate from the external environment's influence because the organization as a system always interacts with its environment (Poerwanto, Sisibintari, \& Suhartono, 2015). An organization that is not responsive and adaptive to developing a complex and uncertain environment is certainly not beneficial. The organization is facing a world of increasingly fierce competition.

The organization must develop its capacity to learn new work patterns, values and strategies so that these elements can be transformed into organizational life that is more capable of responding to any organizational challenges (Soetjitro, 2011). The need to transform organizations is a fundamental shift between the relationship between organizations, individuals and society as a whole. Therefore organizational transformation is a major challenge for organizational leaders. Robbins and Judge (2014) state that capability is the current capacity of individuals to perform various tasks in a job. Overall ability consists basically of two sets of factors: intellectual and physical. Employee capability will undergo three tests not to continue their career or become obsolete (using) and are eliminated. All businesses and industries evolve; nothing can survive if it's just a transit. Human resources also evolved, not only technical skills related to their knowledge but also life skills (Sudirlan, Maarif, Affandi, \& Arkeman, 2019). The goal of an institution or company is to develop employee capabilities on an ongoing basis so that employees can perform optimally and contribute optimally to the company. By increasing capabilities, both 
institutions and organizations strive to have the knowledge, skills, and attitudes that can ensure that individuals can achieve good work. Improvement to improve performance in an organization can be done in three areas, namely people, processes, and technology. Organizational factors can also influence process improvement (Iqbal, 2012).

The e-proposal information system for Government Assistance is developed to help facilitate the management and monitoring of government assistance and build a Course and Training Institute (LKP) that receives assistance from the government. This information system is accessed through the address https://banper.binsuslat.kemdikbud.go.id/. The Management Information System is used by the course and training institutions to access government assistance following the technical instructions from the Directorate of Course Guidance and Training. It is hoped that the online application management information system of government assistance can improve government aid distribution in the comprehensive supervision and management of government assistance. Besides, this information system is expected to improve the performance of the distribution of government assistance to school dropouts in an efficient manner.

However, this hope has not yet been fulfilled because, until now, the Online Application Information System for government assistance has not been running according to its function. The distribution of government assistance is not considered effective because the course institutions do not meet the Directorate of Course Guidance and Training needs. However, the Directorate of Course and Training Development continues to develop comprehensive and userfriendly government aid application programs so that they are used optimally. Based on PKK and PKW assistance data in 2018 and 2019, the Directorate of Course and Training Development has realized assistance funds of IDR 360,803,400,000.00 to run PKK and PKW programs. A total of 7,047 educational institutions have received funds of varying amounts to provide education for 160,226 students. Course and training institutions as government partners in distributing PKK and PKW program assistance are required to continue to transform their organizations and improve their human resource capabilities by utilizing the e-tire management information system so that it is expected to obtain output in the form of increased performance with the increasing number of students or participants. courses that follow PKK and PKW programs.

Identification of the problem under study, namely the factors that strengthen or weaken the influence of the relationship between Organizational Transformation and Education, HR Capabilities and Government Assistance Management Information Systems because: (1) Organizational Transformation and Education is still an obstacle in the distribution of government assistance. This system had only been running in 2019, so many course institutions still do not understand the management information system and are ignorant of how to access government assistance; (2) there are still many course institutions that do not have human resources in the field of Information Technology, resulting in problems in applying for government assistance. The appraiser, if the proposal needs to understand the assessment features in the application so that it applied to the assessment carried out per the technical guidelines to speed up appraising the proposal; (3) The Government Assistance Management Information System has not been running optimally because many features need to be developed to streamline the government aid distribution program; and (4) the performance of the distribution of government assistance has declined due to the poor quality of proposal verification and evaluation of proposals. Therefore, this study aims to determine how the influence of organizational transformation, HR capabilities, management information systems, organizational transformation on the performance of government aid distribution. Then, determine how organizational transformation and HR capabilities on government aid distribution through the e-banper management information system. 


\section{Literature Review}

Task performance is the combination of effectiveness and efficiency at doing your core job tasks (Robbins \& Judge, 2014). Institutional performance is an arrangement of financials and nonfinancial related pointers which give understanding with regards to the level of accomplishment of objectives and results (Young-Harry, Oparanma, \& Ejo-Orusa, 2018). Organizational performance is the effort of the organization to achieve its objectives. This includes four major perspectives, namely financial, customer, internal process, and learning \& growth (Azeez \& Yaakub, 2019). Organizational performance is an organizational effort to achieve its goals. It includes four main perspectives, namely financial, customer, internal processes, and learning and growth. Organizational performance is an organizational effort to achieve its goals, related to financial and non-financial continually to achieve its needs effectively. The organizational performance dimension includes the choice of managers for change. Organizational performance is measured using three dimensions: organizational productivity, organizational effectiveness, and industry ranking (Robbins \& Coulter, 2012).

Joseph E. Champoux (2011) stated that organizational change involves moving from the organization's present state to a future or target state. The future state can include a new strategy, changes in the organization's culture, the introduction of new technology, etc. An organizational change process that includes structures and processes to improve performance per the dynamics of the development of the organizational environment (Poerwanto, Sisibintari, \& Suhartono, 2015). Every company that competes in a business environment will have the same goal: win a business competition through the company's competitive advantage. Efforts to achieve competitive advantage made if the company is flexible in responding to changes and developments in the existing business environment through organizational transformation. The approaches used include re-engineering, rethinking, and restructuring organizational designs in the new management literature (Abubakar, 2016). Basically, the transformation organization dimension is divided into three categories: structure, technology, and people (Robbins \& Coulter, 2012). Structural changes include any changes in authority relations, coordination mechanisms, degrees of centralization, job redesigns, or similar structural variables. Technological changes include modifications in the way work are performed or the methods and equipment used. Changing people refer to changes in employee attitudes, expectations, perceptions, and behavior.

Stephen P. Robbins dan Timothy A. Judge (2014) stated that ability is an individual's current capacity to perform the various tasks in a job. Overall abilities are essentially made up of two sets of factors: intellectual and physical. Human resources capability is HRM practices that facilitate businesses to sustain their competitive advantage. Human resource capabilities are HRM practices that facilitate businesses to maintain their competitive advantage (Chuang, Liu, \& Chen, 2015). Ability is a capacity possessed by each individual to carry out their duties. So it concluded that ability is an assessment or measure of what that person does. Basically, a person's overall capability is essentially composed of two factors, namely: intellectual ability and physical ability (Robbins \& Judge, 2014).

A management information system denotes a system consisting of a set of inputs, processes, 
outputs, and feedback to process the data and transform it into significant information to help upgrade the decision-making (Azeez \& Yaakub, 2019). Management information system (MIS) is characterized by the production of periodic reports that managers use for structured and routine tasks. One of the main objectives of the MIS is to increase the efficiency of managerial activities; Different levels of management have different requirements, and MIS can generate scheduled reports or ad hoc reports. The e-proposal information system for government assistance is developed to help facilitate the management and monitoring of government assistance and build a Course and Training Institute (LKP) that receives assistance from the government.

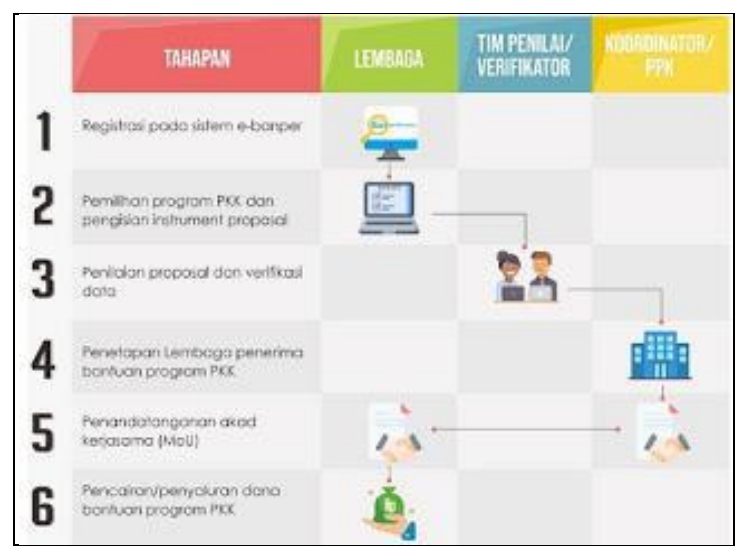

Chart 3, Banper's e-Proposal Mechanism

Banper's e-Proposal mechanism started as registering on the e-banper system, this phase access thru https://banper.binsuslat.kemdikbud.go.id/ page, completing the administrative requirements. Choosing the PKK program and filling out the proposal instrument, this phase assists and completes the proposal instrument's substance requirements and proposes prospective students according to the stipulated requirements. Assessment of proposals and verification of data, when the proposal instrument is complete, it is filled in, then wait for the proposal appraisal process, and if necessary, field verification is carried out. Determining the recipient institutions for PKK program assistance, based on the proposed assessment and field verification results, a plenary meeting will be held to determine which institutions can receive PKK program assistance. Notification of institutions that are eligible to receive PKK program assistance with the approved quota of students will be submitted to the accounts of each institution. Signing the cooperation agreement $(\mathrm{MoU})$. Furthermore, there will be a signing of a cooperation agreement between the organizing institution and the PPK's Directorate of Course and Training. Disbursement/distribution of PKK program assistance funds, disbursement of PKK program assistance funds is carried out through a direct payment mechanism (LS) to the accounts of each implementing agency. Basically, the SIM e-Proposal dimension using information systems effectively requires an understanding of the organization, management, and information technology that make up the system. Information systems create value for companies as organizational and management solutions to challenges posed by the environment (Laudon \& Laudon, 2014).

The hypothesis is a temporary answer to the formulation of the research problem, where the research problem is formulated (Sugiyono, 2017, p. 95). The framework should be designed to facilitate the thinking framework that is derived into a model. Practitioners describe a real problem into a building using specific parameters that are boundaries in the form of shape, structure, content, and meaning to become a model in the decision-making process (Husain, 2019). Therefore, every research paradigm preparation must be based on a frame of mind. 


\section{Journal of Management and Leadership}

Vol.4 No.1, May 2021

Theoretically, it is necessary to explain the relationship between the independent and dependent variables. If in the study there are moderating and intervening variables, it also needs to be explained why these variables were involved in the research (Sugiyono, 2017, p. 60), IPO logic (input-process-output), and a combination of causal models used to formulate alternative hypotheses (Sani, Pusparini, Rizal, Khristiana, Zailani, \& Husain, 2020). The input is in the form of recorded data, namely, primary data taken from the perceptions of course and training institutions that have received government assistance from the Pendidikan Kecakapan Kerja (PKK) and Pendidikan Kecakapan Wirausaha (PKW) on Organizational Transformation and HR Capabilities as determinants, Management Information Systems. e-proposal banper as intervening, which is then processed through data analysis methods with a statistical approach that aims to produce output in Government Aid Distribution Performance. Thus, this research model is defined as follows:

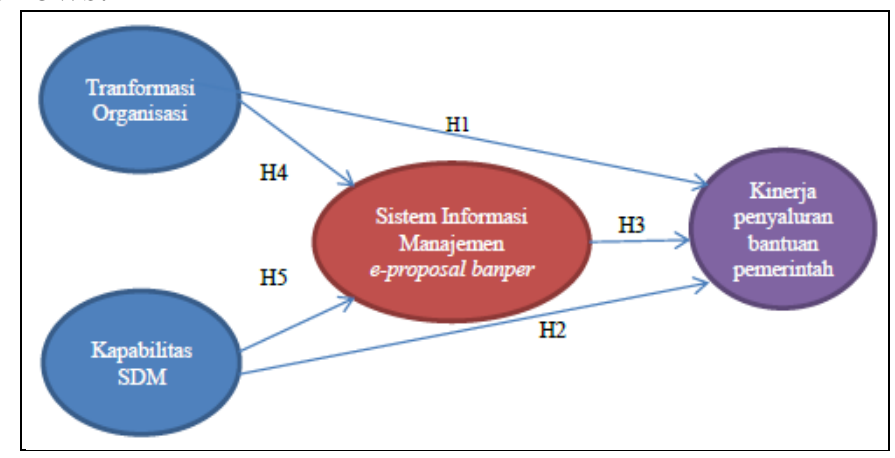

Chart 4, Research Model (adjusted by Author's)

Abubakar (2016), in his research, found that organizational transformation in the form of business process reengineering has a positive effect on organizational performance; this illustrates that business process reengineering aims at cost efficiency, improving customer service, improving quality, and increasing speed which can drive organizational performance improvement. Organizational transformation has a significant effect on the performance of the government bureaucracy (Martini, Suradinata, Kusworo, Lambelanova, \& Thahir, 2019). Organizational change is the restructuring of resources and capabilities to improve organizational performance to create value and increase profits for stakeholders. This first alternative hypothesis is formulated as follows:

$\mathrm{H}_{1}$ : Organizational transformation affects the organizational performance in the distribution of government assistance

Capabilities relevant capabilities in processing information, communication transfer knowledge, coordination between business units, and the ability to trust relationships with consumers and negotiations are factors that determine a company to be more advanced. This second alternative hypothesis is formulated as follows:

$\mathrm{H}_{2}$ : Human resource capabilities affects organizational performance in the distribution of government assistance

Gharaibeh and Malkawi (2013) found that there is no effect of hardware and software equipment on organizational performance; there is a significant effect of networks, individuals and procedures, and management information systems as a whole on the performance of government organizations. Thus the research that proves the effect of management information systems on company organizational performance (Khresat, 2015) This third alternative hypothesis is formulated as follows: 
$\mathrm{H}_{3}$ : Management information system of e-Proposal banper affects organizational performance in the distribution of government assistance

Wijaya (2011) stated that an integrated information system is a valuable asset of a company. If it is properly implemented, the information system will have an added impact and value for the company to be competitive and increase business success in the long term. The application of an integrated information system with the support of information technology can be successful, so it is very much determined by making an organizational change by developing self and competing in a competitive business environment to achieve predetermined profit. The sophistication of information technology and protection of information systems have a positive and significant effect on the effectiveness of information systems (Lisnawati, Wahyuni, \& Julianto, 2017). This fourth alternative hypothesis is formulated as follows:

$\mathrm{H}_{4}$ : Organizational transformation affects the management information system of e-Proposal banper

Information system performance is measured through system user satisfaction and system usage itself. To assess the performance of users of information systems can be viewed from the ability of users of accounting information systems (Robbins \& Judge, 2014). Personal capability has a positive and significant effect on the effectiveness of information systems. This happens because the performance of information systems will run well if users can understand, use, and apply technology to become useful information for decision making. The personal ability of information system users also has a positive and significant effect on information system performance (Lisnawati, Wahyuni, \& Julianto, 2017). This $f$ alternative hypothesis is formulated as follows:

$\mathrm{H}_{5}$ : Human resource capabilities affects the management information system of e-Proposal banper

\section{Methodology}

This method of research is quantitative and qualitative (mixed). Research methods with a combination of two quantitative and qualitative research methods in a research activity so that comprehensive data can be obtained (Sugiyono, 2017). The qualitative research method used in this study is to use the SWOT, CPM, and QSPM analysis. The population in this study were the Course and Training Institutions (LKP) in the Province of DI Yogyakarta, DKI Jakarta, West Java, Central Java, and East Java, which received Pendidikan Kecakapan Kerja (PKK) and Pendidikan Kecakapan Wirausaha (PKW) programs with a total number of 1443 Course and Training Institutions. The sampling technique used purposive sampling technique, namely course and training institutions, that received government assistance from PKK and PKW. The sample in this study was 313.19 , which was determined based on the Slovin calculation formula with an alpha score is 0.05 , but the research takes 500 respondent for this study. The questionnaire as a means of collecting data is measured using an Ordinal scale. All of these instruments are measured using a 'Likert' scale (Kaptein, Nass, \& Markopoulos, 2010; Sani, Wiliani, \& Husain, 2019).

Measurement of the Organizational Transformation variable uses three dimensions with nine indicators: changing structure, changing technology, and changing people (Robbins \& Coulter, 2012). The measurement of the HR Capabilities variable uses two dimensions with ten indicators, namely the dimensions of intellectual ability and physical ability (Robbins \& Judge, 2014). Measurement of the management information system of an e-Proposal variable using 


\section{Journal of Management and Leadership}

Vol.4 No.1, May 2021

three dimensions with ten indicators, namely the dimensions of organization, management, and information technology (Laudon \& Laudon, 2014). Measurement of Organizational Performance in the Distribution of Government Assistance variables uses three dimensions with nine indicators, namely the dimensions of organizational productivity, organizational effectiveness, and industry rankings (Robbins \& Coulter, 2012).

The data analysis technique uses structural equation modeling or SEM for short. This research data processing tool uses the SmartPLS application or software. After that, an evaluation of the SEM model is carried out to obtain and evaluate the suitability proposed and then describe the results of the discussion and conclusions based on the results of the intended analysis.

\section{Result}

\section{Respondent Demographic}

The results of this study begin by presenting the profiles of 500 respondents from the Course and Training Institutions that received PKK and PKW programs based on distribution categories of program types, province, level of education, and length of work.
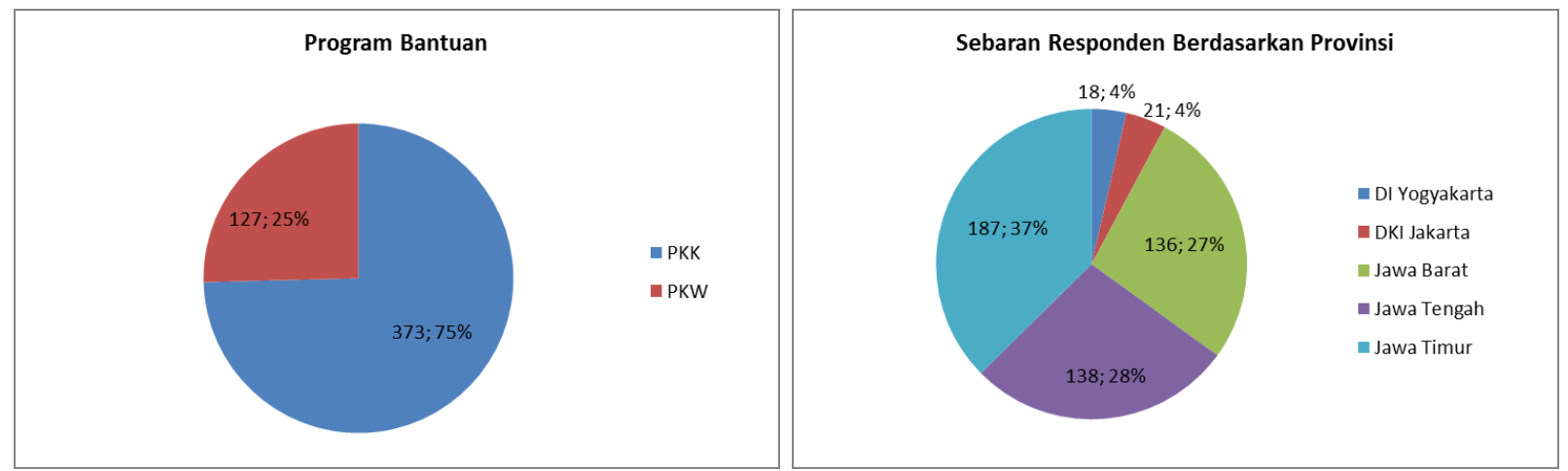

Chart 5, Pie Chart based on PKK and PKW categorize and Province (Processed by Author)

This pie chart 3 presents the criteria for respondents, including 75 percent who received assistance, namely PKK, while 25 percent who received assistance were PKW. Most of them are located in the province of East Java, 37 percent, then in Central Java province at 28 percent, then West Java province at 27 percent, DKI Jakarta, and D.I. Yogyakarta only 4 percent each.

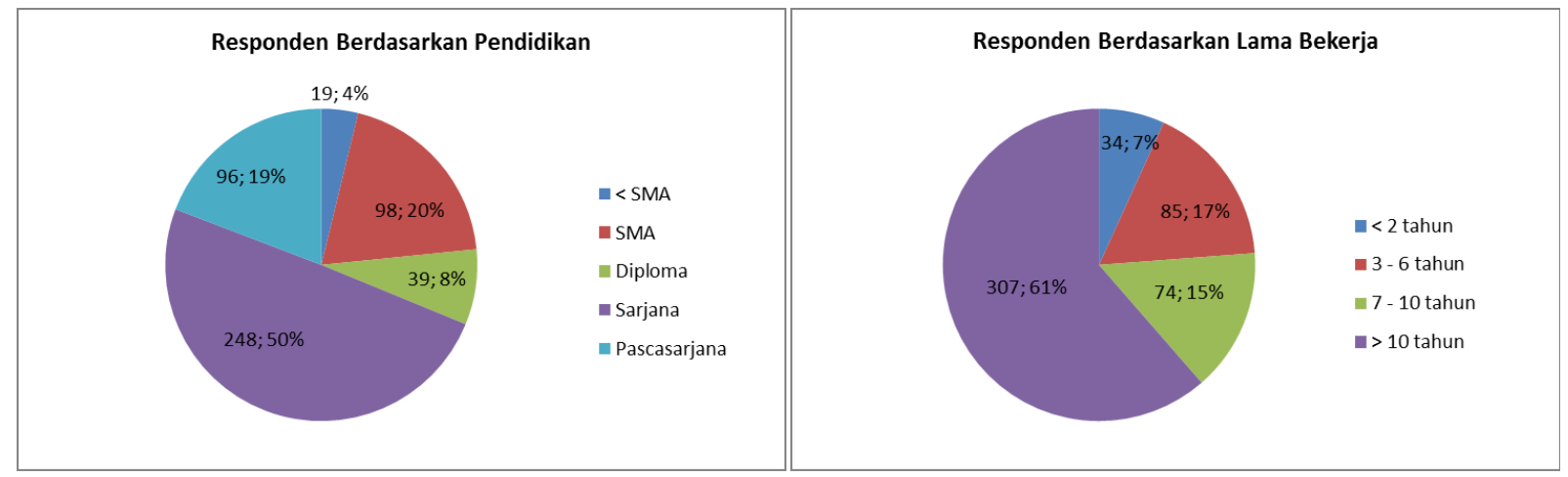

Chart 6, Pie Chart based on Level of Education and length-of work categorize (Processed by Author)

This pie chart 4 presents the criteria for respondents, including 50 percent who have educational 
Vol.4 No.1, May 2021

level is Bachelor, and only 19,4 percent is postgraduate. Most of them have experience is more than ten years as 61 percent, and the remainder have a length of is less than 10 years as 39 percent.

Testing the Measurement Model (Outer Model) provides the output that the latent variable Organizational Transformation using ten indicators only produces three indicators that have $\mathrm{r}$ count which has a loading factor of more than 0.7 , namely the $1^{\text {st }}$ indicator of 0.767 , then $2^{\text {nd }}$ indicator of 0.854 , and $3^{\text {rd }}$ indicator is 0.753 . The rest has a loading factor of less than 0.7. After re-testing the three indicators above, it means that they are declared valid or valid in measuring the Organizational Transformation variable. HR Capabilities using ten indicators produces nine indicators with an r-count, which has a loading factor of more than 0.7, except that the 1st indicator of 0.687 has a loading factor of less than 0.7. After re-testing the nine indicators above, it means that they are declared valid or valid in measuring the HR Capabilities variable. Management Information System of an e-Proposal using ten indicators produces overall indicators with an r-count, which has a loading factor of more than 0.7, it means that they are declared valid or valid in measuring the Information System of an e-Proposal variable. Based on the value of Cronbach's alpha and composite reliability, the resulting scores are 0.703 and 0.835 for the Organizational Transformation variable, 0.934 and 0.944 for the HR Capabilities variable, 0.941 and 0.950 for the Information System of an e-Proposal variable, and 0.889 and 0.912 for the Organizational Performance in the Distribution of Government Assistance variable. Performance. Because all constructs or research instruments have met the measurement model test (outer model), namely convergent validity (greater than 0.70 ) and composite reliability (greater than 0.70), the next step can be hypothesis testing.

Testing the Structural Model (Inner Model), which is used to determine the relationship between latent variables and other latent variables, is tested, including determining the path coefficient value, the value of $\mathrm{R}^{2}$, and determining the $t$-value. The $\mathrm{R}$-square value based on the output yields 0.668 for the Information System of an e-Proposal, and 0.492 for the Organizational Performance in the Distribution of Government assistance (moderate, as it ranges from 0.50 to 0.75). The bootstrapping procedure obtains the values above in SEM, summarized in the PLS output based on the following hypothesis test results.

\section{Tabel 1. Summary of Hypothesis Test Results}

\begin{tabular}{|c|c|c|c|c|}
\hline Hypothesis & Relationship & Coefficient & t-value & Explanation \\
\hline $\mathrm{H}_{1}$ & $\begin{array}{l}\text { Organizational Transformation } \rightarrow \\
\text { Organizational Performance in the } \\
\text { Distribution of Government Assistance }\end{array}$ & 0,024 & 0,503 & No Significant \\
\hline $\mathrm{H}_{2}$ & $\begin{array}{l}\text { HR Capabilities } \rightarrow \text { Organizational } \\
\text { Performance in the Distribution of } \\
\text { Government Assistance }\end{array}$ & 0,237 & 3,503 & Significant Effect \\
\hline $\mathrm{H}_{3}$ & $\begin{array}{l}\text { Management Information System of e- } \\
\text { Proposal } \rightarrow \text { Organizational Performance } \\
\text { in the Distribution of Government } \\
\text { Assistance }\end{array}$ & 0,481 & 8,762 & Significant Effect \\
\hline $\mathrm{H}_{4}$ & $\begin{array}{l}\text { Organizational Transformation } \vec{\rightarrow} \\
\text { Management Information System of e- } \\
\text { Proposal }\end{array}$ & 0,098 & 2,432 & Significant Effect \\
\hline $\mathrm{H}_{5}$ & $\begin{array}{l}\text { HR } \quad \text { Capabilities } \rightarrow \text { Management } \\
\text { Information System of e-Proposal }\end{array}$ & 0,329 & 8,290 & Significant Effect \\
\hline
\end{tabular}




\section{Sumber: Processed by Author, 2020}

The research summary is based on the results of hypothesis testing in Table 1 of each of the effects tested. Organizational Transformation has no impact on Organizational Performance in the Distribution of Government Assistance with a coefficient of 0.024 and a t-value of 0.503 (less than 1.96 , which means $\mathrm{H}_{1}$ is rejected). This finding disagreed with empirical evidence, which shows that Organizational Transformation has a positive influence on organizational performance (Abubakar H. , 2016) and also the findings that prove that Organizational Transformation has a significant influence (Martini, Suradinata, Kusworo, Lambelanova, \& Thahir, 2019). HR Capabilities has impact on Organizational Performance in the Distribution of Government Assistance with a coefficient of 0.237 and a t-value of 3.503 (more than 1.96, which means $\mathrm{H}_{2}$ is accepted). Capabilities relevant capabilities in processing information, communication transfer knowledge, coordination between business units, and the ability to trust relationships with consumers and negotiations are factors that determine a company to be more advanced. Management Information System of e-Proposal impacts Organizational Performance in the Distribution of Government Assistance with a coefficient of 0.481 and t-value of 8.762 (more than 1.96, which means $\mathrm{H}_{3}$ is accepted). This finding disagreed with empirical evidence, which shows that hardware and software equipment does not impact organizational performance (ALGharaibeh \& Malkawi, 2013), but in line with the previous study show that the impact of management information systems on company organizational performance (Khresat, 2015). Organizational Transformation has impact on Management Information System of e-Proposal with a coefficient of 0.098 and a t-value of 2.432 (more than 1.96, which means $\mathrm{H}_{4}$ is accepted). This finding agreed with empirical evidence, which shows that the sophistication of information technology and protection of information systems have a positive and significant influence on the effectiveness of information systems (Lisnawati, Wahyuni, \& Julianto, 2017). HR Capabilities has impact on Management Information System of e-Proposal with a coefficient of 0.329 and a tvalue of 8.920 (more than 1.96, which means $\mathrm{H}_{5}$ is accepted). This finding agreed with empirical evidence, which shows that personal ability of information system users also has a positive and significant influence on information system performance (Lisnawati, Wahyuni, \& Julianto, 2017). The results of the strategy analysis through the input strategy stage with CPM, matching stage with TOWS, and decision stage with QSPM, concluded that the strategy used from the QSPM results is a strategy for developing SIM e-proposal assistance.

\section{Conclusion and Recommendation}

The conclusions of the study include:

a. HR Capabilities and Management Information System of e-Proposal significantly affect Organizational Performance in the Distribution of Government Assistance. In contrast, Organizational Transformation has no significant influence, which on Course and Training Institutions, which received Job Skills Education (PKK) and Entrepreneurial Skills Education (PKW) programs. This is an input for LKP managers that in making changes to their organization, they should socialize well to their employees, make effective communication so that employees understand the goals and benefits of the changes they make.

b. Organizational Transformation and HR Capabilities affect the Management Information System of e-Proposal on Course and Training Institutions, which received Job Skills Education (PKK) and Entrepreneurial Skills Education (PKW) programs. Thus, the LKP management should synchronize management information systems with organizational transformation 
carried out in their institutions. The government assistance of PKK and PKW is used according to their designation for people in need.

c. The results of the strategy analysis through the input strategy stage with CPM, matching stage with TOWS, and decision stage with QSPM, concluded that the strategy used from the QSPM results is a strategy for developing SIM e-proposal assistance.

Other variables can be added by further researchers, such as leadership, compensation, satisfaction, competitive advantage, and so on. For institutions, it is hoped that they can make more creative strategies and master online media and reform human resources to transform towards changes in digitalization. The Directorate of Courses and Training can assist institutions in organizing the management of institutions in digitization. Creating programs to improve the performance of government aid distribution, including providing training in the field of technology for both teaching staff and education personnel.

\section{References}

Abubakar, H. (2016). Effects of Business Process Reengineering on Organizational Performance: Organizational Transformation of Tour and Travel Business. Asian Journal of Applied Sciences, 4(1), 18-25.

AL-Gharaibeh, S. M., \& Malkawi, N. M. (2013). The Impact of Management Information Systems on the Performance of Governmental Organizations- Study at Jordanian Ministry of Planning. International Journal of Business and Social Science, 4(17, Special Issue), 101-109.

Anggraeni, R. (2019, November 5). Angka Pengangguran di Indonesia Capai 7,05 Juta di Agustus 2019. Retrieved September 12, 2020, from SINDOnews.com: https://ekbis.sindonews.com/berita/1455746/34/angka-pengangguran-di-indonesia-capai705-juta-di-agustus-2019

Azeez, R. T., \& Yaakub, K. B. (2019). The Effect of Management Information System on Organizational Performance: A Survey Study at Missan Oil Company in Iraq. Journal of Global Scientific Research (2), 135-165.

Champoux, J. E. (2011). Organizational Behavior : Integrating Individuals, Groups, and Organizations ( ${ }^{\text {th }}$ Ed.). New York, 10016: Routledge 270 Madison Avenue.

Chuang, H.-M., Liu, M.-J., \& Chen, Y.-S. (2015). The Effects of Human Resource Capability and Internal Customer Satisfaction on Organizational Effectiveness. International Journal of Distributed Sensor Networks, 11(7).

Chwelos, P., Benbasat, I., \& Dexter, A. S. (2001). Research Report: Empirical Test of an EDI Adoption Model. Information Systems Research, 12(3), 304-321.

Husain, T. (2019). An Analysis of Modeling Audit Quality Measurement Based on Decision Support Systems (DSS). European Journal of Scientific Exploration, 2(6), 1-9.

Husain, T. (2017). Analisis Determinan Faktor-Faktor Yang Mempengaruhi Niat Penggunaan Software Audit. Jurnal Ilmiah Matrik, 19(2), 131-150.

Iqbal, J. (2012). Towards A Conceptual Framework For Implementation Of Business Process Reengineering (BPR) Initiative. Interdisciplinary Journal of Contemporary Research in Business, 3(11).

Kaptein, M. C., Nass, C., \& Markopoulos, P. (2010). Powerful and consistent analysis of likerttype rating scales. In E. Mynatt (Ed.), CHI '10: Proceedings of the SIGCHI Conference on Human Factors in Computing Systems (pp. 2391-2394). Atlanta Georgia USA: SIGCHI.

Kemendikbud RI. (2020). Laporan Akuntabilitas Kinerja Instansi Pemerintah Direktorat Pembinaan Kursus dan Pelatihan Tahun 2019. LAKIP, Jakarta.

Kemendikbud RI. (2020). SMK BISA-HEBAT: Direktorat Sekolah Menengah Kejuruan. 
Direktorat Sekolah Menengah Kejuruan. Jakarta: Direktorat Jenderal Pendidikan Vokasi, Kementerian Pendidikan dan Kebudayaan.

Khresat, A. (2015). The Effect of Management Information System on Organizational Performance: Applied Study on Jordanian Telecommunication Companies. Information and Knowledge Management, 5(6), 45-51.

Laudon, K. C., \& Laudon, J. P. (2014). Management Information Systems: Managing the Digital Firm (13 ${ }^{\text {th }}$, Global Ed.). Londong: Pearson Education, Ltd.

Lisnawati, N. K., Wahyuni, M. A., \& Julianto, I. P. (2017). Pengaruh Personal Capability, Kecanggihan Teknologi Informasi, Perlindungan Sistem Informasi Dan Partisipasi Manajemen Terhadap Efektivitas Sistem Informasi Akuntansi Pada LPD se-Kecamatan Ubud. e-Journal S1 Ak Universitas Pendidikan Ganesha, 8(2).

Martini, A., Suradinata, E., Kusworo, Lambelanova, R., \& Thahir, M. I. (2019). The Effect of Organizational Transformation, Compensation and Organizational Culture on Performance of Regional Government Bureaucracy in Sumedang Regency West Java Province. Journal of Public Administration and Governance, 9(1), 236-252.

Permendikbud RI. (2018). Peraturan Menteri Pendidikan dan Kebudayaan Republik Indonesia Nomor 12. Tahun 2018 tentang Perubahan atas Peraturan Menteri Pendidikan dan Kebudayaan Nomor 22 Tahun 2015 tentang Rencana Strategis Kementerian Pendidikan dan Kebudayaan Tahun 2015-2019. Peraturan, Jakarta.

Poerwanto, Sisibintari, I., \& Suhartono. (2015). Transformasi Organisasi : Basis Peningkatan Sumber Daya Manusia dalam Memperkuat Daya Saing. Jurnal Al-Azhar Indonesia Seri Pranata Sosial, 2(2), 119-132.

Robbins, S. P., \& Coulter, M. A. (2012). Management (11 ${ }^{\text {th }}$ Ed.). Upper Saddle River, New Jersey: Pearson Education Limited.

Robbins, S. P., \& Judge, T. A. (2014). Perilaku Organisasi-Organizational Behavior (12 ${ }^{\text {th }}$ Ed.). (D. Angelica, R. Cahyani, \& A. Rosyid, Trans.) Jakarta: Erlangga.

Sani, A., Pusparini, N. N., Rizal, R., Khristiana, Y., Zailani, A. U., \& Husain, T. (2020). EBusiness Adoption Models in Organizational Contexts on The TAM Extended Model: A Preliminary Assessment. 2020 8th International Conference on Cyber and IT Service Management (CITSM) (pp. 1-5). Pangkalpinang: UIN Syarif Hidayatullah.

Sani, A., Wiliani, N., \& Husain, T. (2019). Spreadsheet Usability Testing in Nielsen's Model among Users of ITSMEs to Improve Company Performance. European Journal of Scientific Exploration, 2(6), 1-9.

Sani, A., Wiliani, N., Budiyantara, A., \& Nawaningtyas, N. (2020). Pengembangan Model Adopsi Teknologi Informasi terhadap Model Penerimaan Teknologi diantara UMKM. JITK (Jurnal Ilmu Pengetahuan Dan Teknologi Komputer), 5(2), 151-158.

Sarwani, \& Husain, T. (2021). The Firm's Value Empirical Models in Automotive and Components Subsectors Enterprises: Evidence from Developing Economy. Journal of Governance and Regulation, 10(1), 83-95.

Soetjitro, P. (2011). Transformasi Organisasi Menggunakan Pendekatan 4R. VALUE ADDED: Majalah Ekonomi dan Bisnis, 8(1).

Sudirlan, I., Maarif, M. S., Affandi, J., \& Arkeman, Y. (2019). Peningkatan Kapabilitas Karyawan dan Penerapan Budaya Baru Perusahaan dalam Mewujudkan Daya Saing. JKBM (Jurnal Konsep Bisnis dan Manajemen), 5(2).

Sugiyono. (2017). Metode Penelitian Evaluasi: Pendekatan Kuantitatif, Kualitatif, dan Kombinasi. Bandung: CV. Alfabeta.

Tjiptono, F. (2019). Pemasaran Jasa: Prinsip, Penerapan, dan Penelitian (Cetakan 1) (II Ed.). Yogyakarta: Penerbit Andi. 


\section{Journal of Management and Leadership}

Vol.4 No.1, May 2021

Wijaya, E. E., \& Dien Novita. Pengaruh Efektivitas Sistem Informasi Administrasi PT. LG Electronics Indonesia Cabang Palembang Terhadap Kinerja Karyawan, Jurusan Sistem Informasi, STMIK Global Informatika MDP.

Wijaya, S. F. (2011). Pengaruh Teknologi Informasi dan Perubahan Organisasi dalam Bisnis. Seminar Nasional Aplikasi Teknologi Informasi (SNATI) (pp. A-64-A70). Yogyakarta: Universitas Islam Indonesia.

Young-Harry, D. L., Oparanma, A. O., \& Ejo-Orusa, H. A. (2018). Management Information System and Organizational Performance of Seven-Up Bottling Company in Aba and Port Harcourt. IIARD International Journal of Economics and Business Management, 4(4), 53-61. 